\title{
Markets and Measurement: Audit Cultures, Commodification, and Class Strategies in Education
}

\author{
Michael W. Apple \\ (University of Wisconsin-Madison)
}

\section{Introduction}

Most of us living in the United States are now familiar with the key elements of the federal reauthorization of the Elementary and Secondary Education act, commonly known as No Child Left Behind, passed by Congress in 2001 and signed by President Bush in January 2002. This represents a set of initiatives that can radically transform the federal role in policing and controlling core aspects of education. ${ }^{(1)}$ The major components of the legislation center around testing and accountability, but also provide inroads toward a larger agenda of privatization and marketization.

The major provisions include the following:(2)

1. There must be regular testing in key subjects. Thus, starting in 2002-2003, states must engage in an annual assessment of English language proficiency for students who are learning the English language. By the year 2005-2006 annual tests in mathematics and reading/language arts must be given to all children in grades $3-8$. By the year 2007-2008, science tests are added at specific grade levels. Finally, to check on the accuracy of the tests that each state has developed, states have to administer the NAEP (National Assessment of Educational Progress) tests to a portion of their students in grades 4 and 8.

2. The tests that states develop must be aligned with each state's standards and must have results that are comparable from year to year. The tests are to be used both to determine whether the state is indeed meeting its stan- 
dards and in theory to assist teachers in diagnosing the academic problems and needs of students.

3. The scores on these tests are to be disaggregated so that the average scores of specific populations (for example, by race/ethnicity, income, disability, limited English proficiency) are visible.

4. With the above disaggregated information, a state is to follow a specific timeline to close any gaps in achievement among racial/ethnic and income groups. Starting with the year 2002-2003, states have 12 years for all students to move to the state benchmark for mathematical and reading proficiency.

5. At least $95 \%$ of all students in each school must be tested. Every group of students in each school needs to meet or exceed their annual objectives. Failure to meet these objectives leads to formal notification and for those schools receiving Title I money it can lead to various kinds of interventions.

This involves technical assistance if a Title I- a key source of federal funding-school has not met its performance objectives for 2 consecutive years. As well, parents have a choice to send their children to another public school within the school district. After 3 consecutive years of failure, the assistance and choice options continue, but an additional option now comes into play. Students can now use their share of Title I funding to pay for tutoring and other supplemental services. The expenditure of this money is not limited to public institutions, but is expanded to cover other state-approved entities such as religious institutions, for-profit companies, or a private non-profit institution.

If a school continues to fail for a 4 th consecutive year, there is a continuation of assistance, public school choice, and the above noted public or private supplemental services. However, now the school itself is required to make fundamental alterations such as staffing changes. By the 5th year, a school can be required to make changes in its governance. This might include transforming itself into a charter school, having the state itself take over the school, or turning school management over to a private company.

6. Report cards are to be issued annually, publicly documenting a school's achievement levels. Parents also have the right to get information on 
teacher qualifications at their school.

7. In core academic subjects, a state's teachers must all be highly qualified by 2005-2006. This will be demonstrated usually through the use of a state test of subject matter and pedagogical skill in addition to certification and degree requirements. Newly hired paraprofessionals who engage in instruction and are paid through Title I funds must pass a rigorous test or must document that they have at least 2 years of post-secondary education. Already employed paraprofessionals have a few more years in order to meet these requirements.

8. More flexibility is given to school systems in the use of federal money. This enables them, for example, to use Title I funding more flexibly in any school that has at least $40 \%$ of its children as poor, rather than the older criterion of $50 \%$. The legislation also allows schools to shift half of the funds they get from 4 specific federal programs among these programs in ways that they find useful.

9. In addition to making changes in how federal money is distributed so that more money goes to the poorest districts, more money was appropriated for the poorest districts.

10. New initiatives are established. These include such things as the "Teacher Quality" program that helps school districts in their efforts to recruit, retain, and provide professional development to teachers and administrators, and "Reading First," a program that is aimed at reforming the ways in which reading is taught in schools throughout the country.

There are of course other important elements included in the No Child Left Behind legislation. It should be immediately clear that the proposals incorporate a number of progressive sounding issues and are couched in seemingly progressive language. This is partly a result of the compromises made in order to get the legislation passed with bipartisan support in Congress. But it also continues an established tradition of the conservative production of discourse that incorporates progressive language, while simultaneously advancing key elements of the neo-liberal and neo-conservative agendas. It in essence creates what Smith and others have called a "political spectacle," one in which proposals that seemingly 
lead to reforms that are wanted by the least powerful actors in society are instead largely used to gain legitimacy for very different kinds of agendas and policies. $^{(3)}$

Because of both the history of such political spectacles and the realities of inequalities in our society, many of the provisions of NCLB, and their hidden effects and connections to other aspects of the conservative agenda, are-and should be-controversial. Controversies continue to swirl and intensify around such things as its redefinition of literacy and reading instruction and its emphasis on only one set of strategies for teaching such things. There are major questions as well about its budget priorities and about whether the supposed increase in funding is "real" or not. To these, others can be added. Its redefinition of accountability as reducible to scores on standardized achievement tests, and used inappropriately for comparative purposes, is more than a little problematic. The manner in which NCLB defines success and failure, and the shaming practices associated with these processes, has caused numerous complaints and even rebellions in some states and districts. The accompanying loss of local control has also been a consistent worry.

There has been little thought about effects as well on the ways in which the constant stress on "failing public schools" can act to make such things as home schooling - one of the fastest growing transformations in education today, with many more children and parents involved than in charter schools or voucher programs - that much more attractive. With little accountability at all in home schooling, the stress on reductive forms of accountability in NCLB can have the paradoxical effect of actually creating a situation in which ever more children are educated in institutions that have minimal if any forms of public accountability. ${ }^{(4)}$

Further, the clear implication that what counts as good teaching is to be evaluated only on improvements in students' scores on the tests is less than satisfactory and shows a profound misunderstanding of the complexity of the teaching act. The ways in which it tacitly defines what counts as legitimate knowledge as only that which can be included on such reductive tests flies in the face of decades of struggle over the politics of official knowledge and over the 
inclusion of the cultures, languages, histories, values, and habitus of a country made of cultures from all over the world. ${ }^{(5)}$ Not least, as Valenzuela and her colleagues have so clearly demonstrated, this assemblage of "reforms" has had truly damaging consequences for a large number of our most dispossessed peoples, with race/ethnicity being a prime marker of these negative consequences. $^{(6)}$

All of these issues are crucial, and I have talked about a number of them elsewhere. ${ }^{(7)}$ But within the limited context of this article, of particular concern to me here is point 5 in the description of the legislation given above. This is a key element, since it sutures together the requirements of strong accountability measures with an even further opening toward funding for private education. Even though many conservative members of Congress had to back away from their original plan to include federal support for vouchers in the legislation, it would be a grave mistake to not see the connection between privatization and increased federal control and intervention through testing. As Valenzuela has documented in Texas, for example, these connections are often very overt in the political actions of conservative advocates. ${ }^{(8)}$ As a number of researchers have made clear, the politics of race and the contradictory impulses and effects involved in such politics need to be taken very seriously in thinking about all of this. ${ }^{(9)}$

Elsewhere I have argued that there is no contradiction between supposedly decentralized market-based models of education and centralization through strong regimes of curricular control, testing, and accountability. ${ }^{(1)}$ Indeed, the movement toward marketization and "choice" requires the production of standardized data based on standardized processes and "products" so that comparisons can be made and so that "consumers" have relevant information to make choices on a market.

I and many others have documented the negative effects of such "reforms" elsewhere. In this article, I want to focus on the logics that underpin interventions such as No Child Left Behind and similar initiatives, on the creative ideological/political work that has gone on to make them acceptable, and on the complicated class dynamics that both created them and are the effects of them. 
In order to do this, I need to lay out the general context and shifting logics in which No Child Left Behind operates, logics that work to place strong state models of accountability in close contact with marketization. NCLB does not stand alone and appears on a terrain on which crucial ideological work has already been done.

\section{Changing Commonsense}

In a number of volumes over the past decade, I have critically analyzed the processes of "conservative modernization"- the complicated alliance behind the wave after wave of educational reforms that have centered around neo-liberal commitments to the market and a supposedly weak state, neo-conservative emphases on stronger control over curricula and values, and "new managerial" proposals to install rigorous forms of accountability in schooling at all levels. (1) The first set of reforms has not demonstrated much improvement in education and has marked a dangerous shift in our very idea of democracy-always a contested concept ${ }^{(2)}$-from "thick" collective forms to "thin" consumer driven and overly individualistic forms. The second misconstrues and then basically ignores the intense debates over whose knowledge should be taught in schools and universities and establishes a false consensus on what is supposedly common in the United States. ${ }^{(13)}$ The third takes the position that "only that which is measurable is important" and has caused some of the most creative and critical practices that have been developed through concerted efforts in some of the most difficult settings to be threatened. ${ }^{(14)}$ Unfortunately, all too many of the actual effects of this assemblage of reforms have either been negligible or negative, or they have been largely rhetorical. ${ }^{(15)}$ This is unfortunate, especially given all of the work that well-intentioned educators have devoted to some of these efforts. But reality must be faced if we are to go beyond what is currently fashionable.

The odd combination of marketization on the one hand and centralization of control on the other is not only occurring in education; nor is it only going on in the United States. This is a world-wide phenomenon. And while there are very real, and often successful, efforts to counter it, ${ }^{(16)}$ this has not meant that the basic assumptions that lie behind neo-liberal, neo-conservative, and new managerial 
forms have not had a major impact on our institutions throughout society and even on our commonsense.

In many nations there have been attempts, often more than a little successful, to restructure state institutions. ${ }^{(17)}$ Among the major aims of such restructuring were: to ensure that the state served business interests; to have the state's internal operations model those used in business; and to "take politics out of public institutions," that is to reduce the possibility that government institutions would be subject to political pressure from the electorate and from progressive social movements. ${ }^{(18)}$ Chubb and Moe's arguments about voucher plans that place educational institutions on a market mirror this latter point, for example. ${ }^{(19)}$

This last point, removing politics from government institutions, is based on a less than accurate understanding not only of the state but of the market as well. While most economics textbooks may give the impression that markets are impersonal and impartial, they are instead highly political as well as inherently unstable. To this, other points need to be added. To guarantee their survival, firms must seek ways of breaking out of the boundaries that are set by state regulation. Increasingly, this has meant that the boundaries established to divide non-market parts of our lives must be pushed so that these spheres can be opened to commodification and profit-making. As Leys reminds us, this is a crucially important issue. "It threatens the destruction of non-market spheres of life on which social solidarity and active democracy have always depended. ${ }^{(20)}$

It is not an easy process to transform parts of our lives and institutions that were not totally integrated into market relations so that they are part of a market. To do this, at least four significant things must be worked on. ${ }^{(2)}$

1. The services or goods that are to be focused upon must be reconfigured so that they can indeed be bought and sold.

2. People who received these things from the state must be convinced to want to buy them.

3. The working conditions and outlook of the employees who work in this sector must be transformed from a model based on collective understandings and providing service to "the public" on the one hand to working to produce profits for owners and investors and subject to market discipline on 
the other.

4. When business moves into what were previously non-market fields, as much as possible their risks must be underwritten by the state.

Under these kinds of pressures, standardized and competitive labor processes begin to dominate the lives of the newly marketized workers. But this is not all. A good deal of labor is shifted to the consumer. She or he now must do much of the work of getting information, sorting through the advertising and claims, and making sense of what is often a thoroughly confusing welter of data and "products. ${ }^{(22)}$ In the process as well, there is a very strong tendency for needs and values that were originally generated out of collective deliberations, struggles, and compromises, and which led to the creation of state services, to be marginalized and ultimately abandoned. ${ }^{(23)}$ Once again, in Leys' words, "The facts suggest that market-driven politics can lead to a remarkably rapid erosion of democratically-determined collective values and institutions. ${ }^{(24)}$

These arguments may seem abstract, but they speak to significant and concrete changes in our daily lives in and out of education. For more than two decades, we have witnessed coordinated and determined efforts not only to reconstruct a "liberal" market economy, but a "liberal" market society and culture. This distinction is important. In Habermas' words, the attempt is to have "system" totally colonize the "life-world." (25) As many aspects of our lives as possible, including the state and civil society, must be merged into the economy and economic logics. Although there will always be counter-hegemonic tendencies, ${ }^{(26)}$ our daily interactions-and even our dreams and desires-must ultimately be governed by market "realities" and relations. In this scenario-and it is increasingly not only a scenario, but also a reality - a society and a culture are not to be based on trust and shared values. Rather, all aspects of that society are to be grounded in and face "the most extreme possible exposure to market forces, with internal markets, profit centers, audits, and 'bottom lines' penetrating the whole of life from hospitals to play-groups' to schools." ${ }^{(27)}$ As Margaret Thatcher once famously put it, "The task is not to just change the economy, but to change the soul."

Interestingly, because of the focus on measurable results and central control 
over important decisions, the federal government's power has actually been sharply enhanced. (The Bush Administration's legislation concerning "No Child Left Behind" - where schools labeled as "failing" on standardized tests are to be subject to market competition and central sanctions-- becomes a good example of this at the level of elementary and secondary schools.) This has been accompanied by a loss of local democracy. At the same time, the role of the state in dealing with the destructive rapaciousness produced by "economically rational" decisions has been sharply reduced. ${ }^{(2)}$

As many people have recognized, behind all educational proposals are visions of a just society and a good student. The neo-liberal reforms I have been discussing construct this in a particular way. While the defining characteristic of neo-liberalism is largely based on the central tenets of classical liberalism, in particular classic economic liberalism, there are crucial differences between classical liberalism and neo-liberalism. These differences are absolutely essential in understanding the politics of education and the transformations education is currently undergoing. Mark Olssen clearly details these differences in the following passage. It is worth quoting in its entirety.

Whereas classical liberalism represents a negative conception of state power in that the individual was to be taken as an object to be freed from the interventions of the state, neo-liberalism has come to represent a positive conception of the state's role in creating the appropriate market by providing the conditions, laws and institutions necessary for its operation. In classical liberalism, the individual is characterized as having an autonomous human nature and can practice freedom. In neo-liberalism the state seeks to create an individual who is an enterprising and competitive entrepreneur. In the classical model the theoretical aim of the state was to limit and minimize its role based on postulates which included universal egoism (the self-interested individual); invisible hand theory which dictated that the interests of the individual were also the interests of the society as a whole; and the political maxim of laissez-faire. In the shift from classical liberalism to neo -liberalism, then, there is a further element added, for such a shift involves a change in subject position from "homo economicus," who naturally 
behaves out of self-interest and is relatively detached from the state, to "manipulatable man," who is created by the state and who is continually encouraged to be perpetually responsive. It is not that the conception of the self-interested subject is replaced or done away with by the new ideals of "neo-liberalism," but that in an age of universal welfare, the perceived possibilities of slothful indolence create necessities for new forms of vigilance, surveillance, "performance appraisal" and of forms of control generally. In this model the state has taken it upon itself to keep us all up to the mark. The state will see to it that each one makes a "continual enterprise of ourselves"... in what seems to be a process of "governing without governing.,"(29)

In attempting to understand this, in Educating the "Right" Way I demonstrated the power of Olssen's point that neo-liberalism requires the constant production of evidence that you are doing things "efficiently" and in the "correct" way by examining the effects on the ground of the suturing together of the seemingly contradictory tendencies of neo-liberal and neo-conservative discourses and practices, for this is exactly what is happening at all levels of education, including higher education. ${ }^{(3)}$ And this is occurring at the same time as the state itself becomes increasingly subject to commercialization. This situation has given rise to what might best be called an audit culture. To get a sense of the widespread nature of such practices, it is useful here to quote from Leys, one of the most perceptive analysts of this growth:

[There is a] proliferation of auditing, i. e., the use of business derived concepts of independent supervision to measure and evaluate performance by public agencies and public employees, from civil servants and school teachers to university [faculty] and doctors: environmental audit, value for money audit, management audit, forensic audit, data audit, intellectual property audit, medical audit, teaching audit and technology audit emerged and, to varying degrees of institutional stability and acceptance, very few people have been left untouched by these developments. ${ }^{(3)}$

The widespread nature of these evaluative and measurement pressures, and their ability to become parts of our commonsense, crowd out other conceptions 
of effectiveness and democracy.

In place of a society of citizens with the democratic power to ensure effectiveness and proper use of collective resources, and relying in large measure on trust in the public sector, there emerged a society of "auditees," anxiously preparing for audits and inspections. A punitive culture of "league tables" developed (purporting to show the relative efficiency and inefficiency of universities or schools or hospitals). Inspection agencies were charged with "naming and shaming" "failing" individual teachers, schools, social work departments, and so on; private firms were invited to take over and run "failing" institutions. ${ }^{(32)}$

The ultimate result of an auditing culture of this kind is not the promised de -centralization that plays such a significant role rhetorically in most neo-liberal self-understandings, but what seems to be a massive re-centralization and what is best seen as a process of de-democratization. ${ }^{(33)}$ Making the state more "business friendly" and importing business models directly into the core functions of the state such as hospitals and education-in combination with a rigorous and unforgiving ideology of individual accountability-these are the hallmarks of life today. ${ }^{(34)}$ Once again, the growth of for-profit ventures such as Edison Schools in the United States, the increasing standardization and technicization of content within teacher education programs so that social reflexivity and critical understanding are nearly evacuated from courses, ${ }^{(35)}$ the constant pressure to "perform" according to imposed and often reductive standards in our institutions of education, and similar kinds of things are the footprints that these constantly escalating pressures have left on the terrain of education.

A key to all of this is the de-valuing of public goods and services. It takes long -term and creative ideological work, but people must be made to see anything that is public as "bad" and anything that is private as "good." And anyone who works in these public institutions must be seen as inefficient and in need of the sobering facts of competition so that they work longer and harder. ${ }^{(36)}$ When the people who work in public institutions fight back and argue for more respectful treatment and for a greater realization that simplistic solutions do not deal with the complexities that they face every day in the real world of schools, univer- 
sities, and communities, they are labeled as recalcitrant and selfish and as uncaring. Sometimes, as in the case of former United States Secretary of Education Page's public comments to what he thought was a sympathetic audience, they are even called "terrorists." And these "recalcitrant, selfish, and uncaring" employees-teachers, academics, administrators, social workers, and almost all other public employees-can then have their labor externally controlled and intensified by people who criticize them mercilessly, often as in the case of major corporations while these same businesses are shedding their own social responsibilities by paying little or no taxes.

I noted earlier that it is not just the labor of state employees that is radically altered; so too is the labor of "consumers." When services such as hospitals and schools are commodified, a good deal of the work that was formerly done by state employees is shifted onto those using the service. Examples of labor being shifted to the "consumer" include on-line banking, airline ticketing and checkin, supermarket self-checkouts, and similar things. Each of these is advertised as enhancing "choice" and each comes with a system of incentives and disincentives. Thus, one can get airline miles for checking in on one's computer. Or as some banks are now doing, there is an extra charge if you want to see a real live bank teller rather than using an ATM machine (which itself often now has an extra charge for using it).

The effects of such changes may be hidden but that does not make them any less real. Some of these are clearly economic: the closing of bank branches; the laying off of large numbers of workers, including in elementary, middle, and secondary schools and in higher education; the intensification of the work-load of the fewer workers who remain. Some are hidden in their effects on consumers: exporting all of the work and the necessary commitment of time onto those people who are now purchasing the service; searching for information that was once given by the government; doing one's banking and airline work oneself; bagging and checking out at supermarkets. ${ }^{(3)}$ The classed and raced specificities of this are crucial, since the ability to do such electronic searching and education for example is dependent on the availability of computers and especially time to engage in such actions. It requires resources-both temporal and financial, to 
say nothing of emotional-that are differentially distributed.

This all may seem so trivial. But when each "trivial" instance is added up, the massiveness of the transformation in which labor is transferred to the consumer is striking. For it to be successful, our commonsense must be changed so that we see the world only as individual consumers and we see ourselves as surrounded by a world in which everything is potentially a commodity for sale. To speak more theoretically, the subject position on offer is the de-raced, de-classed, and de-gendered "possessive individual," an economically rational actor who is constructed by and constructs a reality in which democracy is no longer a political concept but is reduced to an economic one. ${ }^{(38)}$

Mark Fowler, Ronald Reagan's Chair of the Federal Communications Commission, once publicly stated that television is simply a toaster with pictures. A conservative media mogul in England seemed to agree, when he said that there is no difference between a television program and a cigarette lighter. ${ }^{(39)}$ Both positions are based on an assumption that cultural form and content and the processes of distribution are indeed commodities. There are few more important mechanisms of cultural selection and distribution than schools and universities. And under this kind of logic, one might say that educational institutions are simply toasters with students. There is something deeply disturbing about this position not only in its vision of education, but profoundly in its understanding of the lives of the people who actually work in such institutions in the United States and in the often under-funded, under-staffed, and difficult conditions now being experienced there. While it would be too reductive to see educational work merely in labor process terms, the intensification that has resulted from the conditions associated with this assemblage of assumptions has become rather pronounced. ${ }^{(40)}$

Of course, many of us may be apt to see such things as relatively humorous or innocuous. Aren't market-based proposals for such things as schools, universities, health care and so much more just another, but supposedly more efficient, way of making services available. But not only are these ideologically driven "reforms" not all that efficient, ${ }^{(4)}$ the process of privatization is strikingly different than public ownership and control. For example, in order to market 
something like education, it must first be transformed into a commodity, a "product." The product is then there to serve different ends. Thus, rather than schooling being aimed at creating critically democratic citizenship as its ultimate goal (although we should never romanticize an Edenic past when this was actually the case; schooling has always been a site of struggle over what its functions would actually be, with the working class and many women and people of color being constructed as "not quite citizens"), ${ }^{(42)}$ the entire process can slowly become aimed instead at the generation of profit for shareholders or a site whose hidden purpose is to document the efficiency of newly empowered managerial forms within the reconstituted state. ${ }^{(3)}$

The fact that such things as the for-profit Edison Schools in the United States have not generated the significant profits that their investors had dreamed of means that the process of commodification is at least partly being rejected. For many people in all walks of life, the idea of "selling" our schools and our children is somehow disturbing, as the continuing controversy over Channel One, the for -profit television station with advertising now being broadcast in $43 \%$ of all public and private middle and secondary schools in the United States, amply demonstrates. ${ }^{(4)}$ These intuitions demonstrate that in our everyday lives there remains a sense that there is something very wrong with our current and still too uncritical fascination with markets and audits. However, this optimism needs to be immediately balanced by the immense growth of for-profit on-line universities such as the University of Phoenix, an institution that exemplifies the transformation of education into a saleable commodity.

David Marquand summarizes the worrisome tendencies I have been describing in the following way:

The public domain of citizenship and service should be safeguarded from incursions by the market domain of buying and selling... The goods of the public domain-health care, crime prevention, and education-should not be treated as commodities or proxy commodities. The language of buyer and seller, producer and consumer, does not belong in the public domain; nor do the relationships which that language implies. Doctors and nurses do not "sell" medical services; students are not "customers" of their teachers; 
policemen and policewomen do not "produce" public order. The attempt to force these relationships into a market model undermines the service ethic, degrades the institutions that embody it and robs the notion of common citizenship of part of its meaning. ${ }^{(4)}$

I agree. In my mind, public institutions are the defining features of a caring and democratic society. The market relations that are sponsored by capitalism should exist to pay for these institutions, not the other way around. Thus, markets are to be subordinate to the aim of producing a fuller and thicker participatory democratic polity and daily life. ${ }^{(4)}$ It should be clear by now that a cynical conception of democracy that is "on sale" to voters and manipulated and marketed by political and economic elites does not adequately provide for goods such as general and higher education, objective information, media and new forms of communication that are universally accessible, well-maintained public libraries for all, public health, and universal health care. At best, markets provide these things in radically unequal ways, with class, gender, and especially race being extremely powerful markers of these inequalities. ${ }^{(47)}$ If that is the case-even if the definitions of the "public" were and often still are based on the construction of gendered and raced spaces ${ }^{(48)}$ - the very idea of public institutions is under concerted attack. They need to be provided-and defended-collectively. Such things are anything but secondary. They are the defining characteristics of what it means to be a just society. ${ }^{(4)}$

Unfortunately, the language of privatization, marketization, and constant evaluation has increasingly saturated public discourse. In many ways, it has become commonsense-and the critical intuitions that something may be wrong with all of this may slowly wither. Yet, in many nations where conditions are even worse, this has not necessarily happened, as the growth of participatory budgeting, "Citizen Schools," and close relations between teacher education programs and building more socially responsive and critical curricular and pedagogical initiatives in Porto Alegre, Brazil and elsewhere documents. ${ }^{\left({ }^{(5)}\right)} \mathrm{We}$ can learn from these nations' experiences and we can relearn what it means to reconstitute the civic in our lives. This, for example, is one of the reasons the democratic schools movement and the move toward a regeneration of a sense of 
"the public" in the United States is so essential now. ${ }^{(5)}$ Education has a fundamental role to play in doing exactly that. But it can only do so if it is protected from those who see it as one more product to be consumed as we measure it and who interpret the intellectual and emotional labor of those who are engaged in educational work though the lenses of standardization, rationalization, and auditing.

Having said this, however, interrupting conservative modernization requires that we have a more adequate understanding of both some fundamental dynamics and its social functions and roots. I want to turn to this now.

\section{New Managerialism in Class Terms}

Throughout this article, I have been broadly describing particular kinds of tendencies that are reconstructing what counts as legitimate knowledge, legitimate education, legitimate evidence, and legitimate labor. Yet, we need to be cautious about reductive analyses in understanding where these ideological movements come from. It would be too easy to simply say that these are the predictable effects of competitive globalization, of capital in crisis and its accompanying fiscal crisis of the state, or in more Foucauldian terms of the micro-politics of governmentality and normalization, although there is some truth to all of these. These tendencies underpinning "conservative modernization" are also "solutions" that are generated by particular actors, and here we need to be more specific about class relations inside and outside of higher education.

As Basil Bernstein has reminded us and as I have argued at much greater depth elsewhere, a good deal of the genesis of and support for the policies of conservative modernization, and especially of the constant need for audits, the production of "evidence," rationalization, and standardization of both labor and knowledge comes not only from capital and its neo-liberal allies in government, but from a particular fraction of the professional and managerial new middle class. ${ }^{\left({ }^{(52)}\right.}$ This fraction of the professional new middle class gains its own mobility within the state and within the economy based on the use of technical expertise. These are people with backgrounds in management and efficiency techniques 
who provide the technical and "professional" support for accountability, measurement, "product control," and assessment that is required by the proponents of neo-liberal policies of marketization and neo-conservative policies of tighter central control in education.

Members of this fraction of the upwardly mobile professional and managerial new middle class do not necessarily believe in the ideological positions that underpin all aspects of the conservative alliance. In fact in other aspects of their lives they may be considerably more moderate and even "liberal" politically. However, as experts in efficiency, management, testing, and accountability, they provide the technical expertise to put in place the policies of conservative modernization. Their own mobility depends on the expansion of both such expertise and the professional ideologies of control, measurement, and efficiency that accompany it. Thus, they often support such policies as "neutral instrumentalities" even when these policies may be used for purposes other than the supposedly neutral ends this class fraction is committed to. ${ }^{(53)}$

Because of this, it is important to realize that a good deal of the current emphasis on audits and more rigorous forms of accountability, on tighter control, and a vision that competition will lead to greater efficiency is not totally reducible to the needs of neo-liberals and neo-conservatives. Rather, part of the pressure for these policies comes from educational managers and bureaucratic offices who fully believe that such control is warranted and "good." Not only do these forms of control have an extremely long history in education, ${ }^{540}$ but tighter control, high stakes testing, and (reductive) accountability methods provide more dynamic roles for such managers.

Let me briefly say more about this, since this is significant in terms of the self -understanding of class actors within the administrative apparatus of the state. The decades of attacks on state employees have not only had the predictable effects of lost employment and worsening working conditions, although these kinds of things are continuing within education and elsewhere. These attacks also have had profound effects on identities and have produced a crisis among many state employees and managers about doubts to their expertise and their ability to "help" the public. ${ }^{(5)}$ New identities that are centered around enhanced 
technical proficiency and a set of assumptions that deep-seated problems in education and the entire social sphere can be provided by enhancing efficiency and holding people more rigorously accountable for their actions have developed over time, sponsored in part by neo-liberal discourses that have opened spaces within the state for such expertise. This enables those class fractions with technical forms of cultural capital centered around accountability and managerial efficiency to occupy these spaces and to guarantee a place for the uses of their knowledge. This is an ideal situation for the professional and managerial new middle class. They can see themselves as engaging in a moral crusadeseeing themselves as being endlessly responsive to "clients" and "consumers" in such a way that they are participating in the creation of a newly reconstituted and more efficient set of institutions that will "help everyone"-and at the same time enhancing the status of their own expertise. In Bourdieu's terms, this allows for particular kinds of conversion strategies, ones in which their cultural capital (technical and managerial expertise) can be converted into social and economic capital (positions and mobility within education and the state). ${ }^{(5)}$

This needs to be situated in the ways in which such cultural markets and conversion strategies operate in the larger set of class relations in which such new middle class actors participate. My claims here are complicated and I can only outline a wider set of arguments. However, the implications of these arguments are serious if we are to fully understand why all of education, including higher education and who does and does not go there, seems to be experiencing a number of the restructurings I have earlier discussed.

This is a time when competition for credentials and cultural capital is intense. The increasing power of mechanisms of restratification such as the return of high levels of mandatory standardization, more testing more often, and constant auditing of results also provides mechanisms-and an insistent logic--that enhance the chances that the children of the professional and managerial new middle class will have less competition from other students. Thus, the introduction of devices to restratify a population-for this is what much of it is-enhances the value of the credentials that the new middle class is more likely to accumulate, given the stock of cultural capital it already possesses. ${ }^{(57)}$ I am not 
claiming that this is necessarily intentional, but it does function to increase the chances for mobility by middle class children who depend not on economic capital but on cultural capital for advancement. ${ }^{(58)}$ The effects of such policies and procedures on working class students and on students of oppressed minorities is more than a little visible in an entire series of detailed and insightful studies. ${ }^{(59)}$

I want to stress the importance of this element within conservative modernization, not only because it already occupies considerable power within the state. It is crucial to focus on this groups as well because, in the situation I have described, I believe that this group is not immune to ideological shifts to the Right and thus may not be as able to be self-conscious about the role they may be playing in the restructuring of educational and social policies I have been discussing in this article. Given the fear generated by the attacks on the state and on the public sphere by both neo-liberals and neo-conservatives, this class fraction is decidedly worried about the future mobility of its children in an uncertain economic world. Thus, they may be drawn even more overtly to parts of the conservative alliance's positions, especially those coming from the neoconservative elements which stress greater attention to traditional "high status" content, greater attention to testing, and a greater emphasis on schooling (and the entire university system) as a stratifying mechanism. This can be seen in a number of states in the United States, for example, where parents of this class fraction are supporting charter schools that will stress academic achievement in traditional subjects and traditional teaching practices.

It remains to be seen where the majority of members of this class grouping will align in the future in the debates over policy. Given their contradictory ideological tendencies, it is possible that the Right will be able to mobilize them under conditions of fear for the future of their jobs and children, even when they still vote for, say, the Democrats in the US or New Labour in the UK in electoral terms. ${ }^{(6))}$ At the very least, it would be romantic to assume that they will be responsive to the claims from those people who are employed in institutions of higher education and in education in general that the conditions under which they are increasingly working are damaging and that they are creating an 
education that is less and less worthy of its name.

\section{Conclusion}

I began this paper with discussion of the most important educational reform in the United States and a critical overview of certain tendencies within our societies that are embodied in this reform. I pointed to the steady growth of neo -liberal restructurings of institutions and identities, and to the hard and creative ideological work that such transformations require. In the process, I noted that commodification and audit cultures tend to reinforce each other and that these processes are played out on multiple terrains, with education being one of the most significant. I have also asked us to be more specific about the ways in which particular class dynamics may produce these tendencies and not to reduce them to the interests of an undifferentiated group that we might label as, say, "capital." In the process, I have outlined a set of arguments about the role of particular segments of the middle class.

There has been exceptional work done on the ways in which class works in altered contexts such as these. For example, middle class parents often have a store of cultural and social capital that enables them to employ such things as audits and "choice" in education as part of complex conversion strategies that guarantee their own children's advantage. ${ }^{(61)}$ There is also an emerging body of work on how this is related not only to classed actors but to gendered labor, particularly the work of mothers. ${ }^{(62)}$ (However, there has been less attention paid to the ways in which members of historically oppressed "minority" groups, particularly poor persons of color, strategically deal with issues of accountability, marketization, privatization, and "choice" in the United States, something I do elsewhere. $\left.{ }^{(63)}\right)$

In urging us not to assume that these conditions can be reduced to the automatic workings out of simple formulae, I have suggested that we need a much more nuanced and complex picture of class relations and class projects to understand what is happening. But this is not enough. Space considerations do not allow me to do more here than to suggest that it is also crucial to develop a more sensitive and historically grounded analysis of the place, especially in the 
United States given its history of apartheid, of racial dynamics in the vision both of "a world out of control" that needs to be policed and of "cultural pollution" that threatens 'real knowledge' in the growth of markets and audit cultures. ${ }^{(64)}$

Of course, becoming more nuanced about such constitutive dynamics will not guarantee that we can interrupt the tendencies upon which I have focused here. But it is one essential step in understanding the genesis of what is at stake in a serious politics of interruption.

\section{Notes}

(1) Jack Jennings, "From the White House to the School House," in William Lowe Boyd and Debra Miretzky, eds. American Educational Governance on Trial (Chicago: University of Chicago press, 2003), pp. 291-309.

(2) My description here draws on Jennings' clear exposition of the major elements of No Child Left Behind. See Ibid, pp. 299-302.

(3) Mary Lee Smith, et al. Political Spectacle and the Fate of American Schools (New York: RoutledgeFalmer, 2004).

(4) Michael W. Apple, Educating the "Right" Way: Markets, Standards, God, and Inequality 2nd ed. New York: Routledge, 2006 and Michael W. Apple, "Godly Technology," in Michael W. Apple and Kristen L. Buras, eds. The Subaltern Speak (New York: Routledge, 2006).

(5) Michael W. Apple, Official Knowledge: Democratic Education in a Conservative Age, 2nd ed. (New York: Routledge, 2000).

(6) Angela Valenzuela, ed. Leaving Children Behind: How "Texas-Style Accountability Fails Latino Youth (Albany: State University of New York Press, 2005). See also Linda McNeil, The Contradictions of School Reform (New York: Routledge, 2000) and Pauline Lipman, High Stakes Education (New York: Routledge, 2004).

(7) Michael W. Apple, "What Can We Learn from Texas About No Child Left Behind?" Educational Policy, in press.

(8) Angela Valenzuela, "Accountability and the Privatization Agenda," in Valenzuela, Leaving Children Behind, pp. 263-294.

(9) Ibid. 
(10) Apple, Educating the 'Right' Way.

(11) Apple, Official Knowledge; Apple, Educating the 'Right' Way; Michael W. Apple, et al. The State and the Politics of Knowledge (New York: Routledge, 2003). These volumes also pay particular attention to a fourth group, the authoritarian populist conservative evangelical movement, and a growing presence in the struggles over educational policy and practice.

(12) Eric Foner, The Story of American Freedom. New York: Norton, 1998.

(13) See Michael W. Apple, Cultural Politics and Education (New York: Teachers College Press, 1996); Apple, Official Knowledge; Michael W. Apple, Ideology and Curriculum, 3rd ed. (New York: Routledge, 2004); Lawrence Levine, The Opening of the American Mind: Canon, Culture, and History (Boston: Beacon Press, 1996); Amy Binder, Contentious Curricula (Princeton: Princeton University Press, 2002).

(14) McNeil, The Contradictions of School Reform, Lipman, High Stakes Education. Michael W. Apple and James A. Beane (eds), Democratic Schools (Buckingham: Open University Press, 1999), Ira Shor, Empowering Education (Chicago: University of Chicago Press, 1992); Stanley Aronowitz, The Knowledge Factory (Boston: Beacon Press, 2000).

(15) Smith, et al., Political Spectacle and the Fate of American Schools (New York: Routledge, 2003).

(16) Apple, et al., The State and the Politics of Knowledge.

(17) Bob Jessop, The Future of the Capitalist State (Cambridge: Polity Press, 2002).

(18) Colin Leys, Market-Driven Politics: Neoliberal Democracy and the Public Interest (New York: Verso, 2003), 3.

(19) John Chubb and Terry Moe, Politics, Markets, and American Schools (Washington: Brookings Institution, 1990). See also Sheila Slaughter and Larry Leslie, Academic Capitalism (Baltimore: Johns Hopkins University Press, 1999); Sheila Slaughter and Gary Rhoades, Academic Capitalism and the New Economy (Baltimore: Johns Hopkins University Press, 2004); and Robert Rhoads and Carlos Alberto Torres, editors. The Political Economy of Higher Education in America (Stanford, Stanford University Press, in press) for 
thoughtful discussions of the effects of marketization and competitive economic pressures on universities.

(20) Leys, Market-Driven Politics, 4.

(21) Ibid.

(22) See Emily Van Dunk and Anneliese Dickman, School Choice and the Question of Accountability (New Haven: Yale University Press, 2003) for how this works, and doesn't work, in plans to marketize education.

(23) Apple, Official Knowledge; Leys, Market-Driven Politics, 4.

(24) Leys, Market-Driven Politics, 4.

(25) Jurgen Habermas, Knowledge and Human Interests (Boston: Beacon Press, 1971).

(26) Jessop, The Future of the Capitalist State; Apple, Educating the 'Right' Way; Apple et al., The State and the Politics of Knowledge.

(27) Leys, Market-Driven Politics, 35-36.

(28) Ibid, 42; See also Michael B. Katz, The Price of Citizenship (New York: Metropolitan Books, 2001); David Shipler, The Working Poor (New York: Knopf, 2004).

(29) Mark Olssen, "In Defense of the Welfare State and of Publicly Provided Education," Journal of Education Policy 11 (May 1996), 340.

(30) Apple, Educating the 'Right' Way.

(31) Leys, Market-Driven Politics, 70.

(32) Ibid.

(33) Ibid, 71.

(34) Ibid, 73.

(35) Daniel Liston and Kenneth Zeichner, Teacher Education and the Social Conditions of Schooling (New York: Routledge, 1991); Apple, Educating the 'Right' Way; Dale Johnson, et al., Trivializing Teacher Education (New York: Rowman and Littlefield, 2005).

(36) John Clarke and Janet Newman, The Managerial State (Thousand Oaks, CA: Sage, 1997).

(37) Of course, this is a differentiated experience. In the United States, supermarkets are less apt to even be found in inner city neighborhoods populated by 
poor persons of color.

(38) Stephen Ball, Education Reform (Buckingham: Open University Press, 1994); Apple, Educating the 'Right' Way.

(39) Leys, Market-Driven Politics, 108.

(40) Michael W. Apple, Education and Power (New York: Routledge, 1995); Apple, Official Knowledge.

(41) Apple, Educating the 'Right' Way; Lipman, High Stakes Education.

(42) See Apple, Official Knowledge; David Hogan, 'Education and Class Formation,' in Cultural and Economic Reproduction in Education, ed. Michael W. Apple (Boston: Routledge and Kegan Paul, 1983). For the ways in which race has been and is a crucial dynamic, see Charles Mills, The Racial Contract (Ithaca: Cornell University Press, 1997); Cameron McCarthy, Warren Crichlow, Greg Dimitriadis, and Nadine Dolby (eds), Race, Identity, and Representation in Education, 2nd ed. (New York: Routledge, 2005); Gloria LadsonBillings and David Gillborn (eds), The RoutledgeFalmer Reader in Multicultural Education (London: RoutlegeFalmer, 2004); Michelle Fine, Lois Weis, Linda Powell, and L. Mun Wong (eds), Off White, 2nd ed. (New York: Routledge, 2005).

(43) Leys, Market-Driven Politics, 211-212.

(44) Apple, Official Knowledge.

(45) David Marquand, The Progressive Dilemma (London: Phoenix Books, 2000), 212-213.

(46) Theda Skocpol, Diminished Democracy (Norman, OK: University of Oklahoma Press, 2003).

(47) Katz, The Price of Citizenship.

(48) Nancy Fraser, Unruly Practices (Minneapolis: University of Minnesota Press, 1989); Robin D. G. Kelly, 'We Are Not What We Seem: Rethinking Black Working Class Opposition in the Jim Crow South', The Journal of American History 80 (June 1993), 75-112; See also Michael W. Apple and Thomas Pedroni, 'Conservative Alliance Building and African American Support for Voucher Plans', Teachers College Record 107 (September 2005), 2068-2105, however, on how oppressed people attempt to tactically take up the 
subject position of the consumer and rearticulate it to further their own collective interests.

(49) Leys, Market-Driven Politics, 220.

(50) Apple et al., The State and the Politics of Knowledge.

(51) See Michael W. Apple and James A. Beane, eds. Democratic Schools (Alexandria, VA: Association for Supervision and Curriculum Development, 1995) and Skocpol, Diminished Democracy.

(52) Basil Bernstein, Pedagogy, Symbolic Control and Identity (Philadelphia: Taylor and Francis, 1996); Apple, Educating the 'Right' Way.

(53) Basil Bernstein makes an important distinction between those fractions of the new middle class that work for the state and that group who works in the private sector. They may have different ideological and educational commitments. See Basil Bernstein, The Structuring of Pedagogic Discourse (New York: Routledge, 1990). For more on the ways 'intermediate' classes and class fractions operate and interpret their worlds, see Erik Olin Wright, (ed.), The Debate on Classes (New York: Verso, 1998), Erik Olin Wright, Classes (New York: Verso, 1985), Erik Olin Wright, Class Counts (New York: Cambridge University Press, 1997), and Pierre Bourdieu, Distinction (Cambridge: Harvard University Press, 1984).

(54) Apple, Ideology and Curriculum.

(55) Clarke and Newman, The Managerial State.

(56) Bourdieu, Distinction.

(57) See Bourdieu, Distinction; Pierre Bourdieu, Homo Academicus (Stanford: Stanford University Press, 1988); Pierre Bourdieu, The State Nobility (Stanford: Stanford University Press, 1996).

(58) Sally Power, Tony Edwards, Geoff Whitty, and Valerie Wigfall, Education and the Middle Class (Buckingham: Open University Press, 2003); Stephen Ball, Class Strategies and the Education Market (London: RoutledgeFalmer, 2003).

(59) See David Gillborn and Deborah Youdell, Rationing Education (Buckingham: Open University Press, 2000); McNeil, The Contradictions of School Reform; Lipman, High Stakes Education; Apple, Cultural politics and Educa- 
tion, Apple, Official Knowledge; Apple, Educating the 'Right' Way.

(60) Ibid

(61) Ball, Class Strategies and the Education Market, Power, Edwards, Whitty, and Wigfall, Education and the Middle Class and Gillborn and Youdell, Rationing Education.

(62) Alison Griffith and Dorothy Smith, Mothering for Schooling (New York: Routledge, 2005).

(63) There has been some discussion of the dangers of voucher plans by African American nationalist activists and scholars. See L. Bush, "Access, School Choice, and Independent Black Institutions," Journal of Black Studies 34 (2004), 386-401. On Black activism and the ways in which consumer struggles have led to positive effects both within dominant white controlled economic and political institutions and within Black mobilizations as well, see S. K. Sewell, "The "Not-Buying" Power of the Black Community, The Journal of African American History 89 (2004), 135-151.

(64) See, for example, Apple and Pedroni, "Conservative Alliance Building and African American Support of Vouchers," Apple, Educating the "Right" Way, and Apple and Buras, The Subaltern Speak. 